\title{
WHEN AN ERROR LEADS TO CONFIDENCE: FALSE INSIGHT AND FEELING OF KNOWING IN ANAGRAM SOLVING
}

\author{
A.V. AMMALAINEN ${ }^{\mathrm{a}}$, N.V. MOROSHKINA ${ }^{\mathrm{a}}$
}

\begin{abstract}
${ }^{a}$ Saint Petersburg State University, 7/9 Universitetskaya emb., Saint Petersburg, 199034, Russian Federation
\end{abstract}

\begin{abstract}
Solutions accompanied by Aha!-experiences are called insights, or, if they are wrong, false insights. Classical theories cannot give an explanation for false insight because they consider Aha!-experience and other metacognitive feelings just as side effects of the cognitive processes. From this perspective, dissociations between cognition and metacognition are impossible. According to the signal theories of insight, metacognitive feelings, including Aha!-experience, form in two stages. Finding a solution on the unconscious level causes a non-specific emotional signal that is attributed by consciousness to any process or task. In this case, false insight and other dissociations between cognitive and metacognitive processes appear because of the misattribution of the signal. The current work tests this hypothesis. We suggested that solving an interfering problem unconsciously would lead to false insights or higher feeling of knowing ratings. We created a method of the false semantic hint to simulate this situation in the experiment. The problems were anagrams with one solution and one word shorter by one letter inside them. The false hints were pictures that referred to shorter words inside the anagrams. We found that participants tend to make more intrusion errors after this type of priming. This proves our method to be working and means that the signal from an interfering problem might be attributed to the main one. Also, the feeling of knowing ratings after intrusion errors were higher than after omission errors. This result can be interpreted as an aftereffect of the initial metacognitive signal and a possibility of its repeated attribution.
\end{abstract}

Keywords: problem solving, semantic priming, Aha!-experience, insight, feeling of knowing, anagrams, metacognitive experiences.

\section{Introduction}

Insight, or the so-called Aha!-experience, is a moment of illumination, a sudden understanding of the problem. It has been studied for almost a hundred years since Köhler introduced the term, but today psychologists still argue about its nature. There are two levels involved in insight problem solving. The cognitive level consists of particular mechanisms that determine finding of a solution. Some 
researchers (Duncker, 1926; Ohlsson, 1992) assumed a representational change as such mechanism while other (Poincaré, 1910; Dorfman, Shames, \& Kihlstrom, 1996) believed that implicit processes produce new associations, some of which are crucial to the solution. The metacognitive level includes everything one experiences during problem solving. Usually, researchers emphasize a subjective impasse, a sudden popping up of the solution, high confidence in the accuracy of the answer, and pleasure (Bowden, 1997).

Although insight is defined by different metacognitive experiences, traditional theories were intended to explain only cognitive mechanisms of problem solving. Metacognitive experiences were considered as an epiphenomenon (Newell \& Simon, 1972) or just an indicator of the special insight processes (Metcalfe, 1986). However, it was not possible to explain the dissociations between cognitive and metacognitive levels (e.g., hindsight or overconfidence) from this perspective. It became clear after discovering them that subjective experience is not merely a reflection of cognitive processes. Researchers began to study metacognition as an independent phenomenon trying to understand its nature and possible functions. In problem solving, the example of dissociation between two levels is a so-called false insight, which is a finding the wrong solution accompanied by the Aha!-experience (Danek \& Wiley, 2017).

The shift of researches' attention from cognitive to metacognitive processes (for review, see Tikhonov, Ammalainen, \& Moroshkina, 2018) determined the appearance of new theories of insight that we will call the signal theories. According to them, metacognitive experiences, including the Aha!-experience, form in two stages. The first one is a non-specific signal sent to consciousness by the unconscious system, and the second one is its attribution to a particular process. From this perspective, false insights can be explained as the misattribution of the initial signal.

There are different variations of the signal theories of insight. Perhaps, the most popular is the processing fluency theory (Reber, Schwarz, \& Winkielman, 2004). In a nutshell, it tells that metacognitive experiences reflect the ease with which information is processed. S. Topolinski and R. Reber (2010) attempted to apply the theory to insight problem solving. They suggested that when the solution is found, the whole problem is processed with high fluency that, being attributed to the solution, causes an Aha!-experience.

Another author claiming the signal role of Aha!-experience is V. Allakhverdov. He describes an insight phenomenon as a part of the general framework of consciousness. According to the framework, there are parallel cognitive modules (cognition loops) in unconsciousness that process information differently (Allakhverdov et al., 2015; Allakhverdov \& Gershkovich, 2010). The researcher emphasizes the necessity for these loops to be independent to compare their outputs. If different systems get the same result by different ways, it is more likely to be reliable. Thus, the solution to a problem is discovered without consciousness, and when the matching block evaluates it, consciousness gets a signal. Allakhverdov calls it a non-specific emotional signal because it does not include information about the solution and the way it was obtained. After getting the signal, consciousness has to attribute it to the relevant problem. 
E.A. Valueva and D.V. Ushakov introduced their model of insight (based on Allakhverdov's framework) that takes into account different patterns of activation (Valueva \& Ushakov, 2015). Another similar model is the Eureka heuristic model provided by R. Laukkonen and colleagues (Laukkonen, Schooler, \& Tangen, 2018). In this model, Aha!-experience is considered as a simple way to evaluate the answer found unconsciously. The Aha!-moment is experienced when the solution is consistent with the activated "structures of implicit knowledge." People use this heuristic when there is a lack of time or explicit information to check the solution.

All of the theories/models mentioned above have a common point: an attribution stage in the formation of metacognitive experiences. From this perspective, false insight can be explained as misattribution of the initial signal because it does not communicate the information about its source. It is not surprising that signals might be confused with each other and be attributed to the wrong sources. We assume that if we have an interfering problem, the signal might be attributed to it instead of the relevant one. It will cause false insight or, considering that the error is detected quickly, a so-called feeling of knowing (FOK), i.e. confidence about being able to solve the problem (Metcalfe, 1986).

\section{Method}

\section{Participants}

Forty-three native Russian speakers (32 female) participated in this study. The mean age was 22.9. Two participants reported rich experience in solving anagrams but they did not perform better than others according to the data.

\section{Materials}

Thirty anagrams were created for the experiment. Each anagram had a solution which was a 5-, 6- or 7-letter Russian noun. The anagrams included two words: the solution and a word shorter by one letter. For example, the solution to the anagram “едоевпр" іs “перевод" (Rus. "translation"). But there is another word inside the anagram: “дерево" (Rus. "tree”) which is shorter than the correct answer by one letter. In the pilot study, four subjects solved 200 anagrams, and those within the solving time ranged from $\mathrm{M}-1.5 \mathrm{SD}$ to $\mathrm{M}+2 \mathrm{SD}$ were chosen because the anagrams needed to be difficult enough to have a lot of misses in the experimental session.

We created a special method with a false semantic hint. The idea of the false semantic hint method is to prime a participant with the picture of a shorter word. It would present an interfering problem of matching the picture and the letters. The pictures were picked for each short word included in the anagram. We asked another four subjects to name pictures with five words. The picture was considered suitable if it was named with the word we assumed by at least two people. The design included four conditions:

1. Positive priming - the picture is the hint to the solution. 
2. Irrelevant priming - the meaningful picture that has no connection with the anagram.

3. Neutral priming - the picture is a black square.

4. Interfering priming - the picture is the hint to the word shorter than the solution.

Each participant solved thirty anagrams. Twelve of thirty were presented with positive priming and six with each of others. The positive priming was used to keep participants motivated to look at the pictures. The anagrams presented in this condition were the same for all participants and were not included in the analysis. Other anagrams were presented with all types of priming but only with one type for each participant. For this reason, participants were divided into four groups.

\section{Procedure}

The experiment was built using PsychoPy 1.85.3 (Peirce, 2009) and demonstrated using the LCD monitor with the screen size of 13 in. and resolution of $1920 \times 1080$. Participants were tested individually in front of a computer. The pictures appeared on the grey background for $2000 \mathrm{~ms}$ and followed by a $500 \mathrm{~ms}$ white square mask. Participants were told to look at the pictures because they might be relevant to the solution. Then the anagrams written in black text in Arial font with a height of 50 pixels appeared for $15 \mathrm{sec}$ four times (total time $60 \mathrm{sec}$ ). We used a reverse counterbalancing method to set the sequence of anagrams presentation. A mask was presented for $500 \mathrm{~ms}$ after an anagram. The participants' task was to solve the anagram as fast as possible and to press a spacebar when the solution was found. After each trial, participants saw a blank field and the text "Type the answer." After submitting the answer, they got a feedback message about its correctness. If the answer was wrong or participants did not find any solution, they were asked to rate the likelihood they would solve the anagram in the time left with the 7-point scale after second and third trials. The scheme is presented in Figure 1.

Figure 1

Procedure of the Experiment

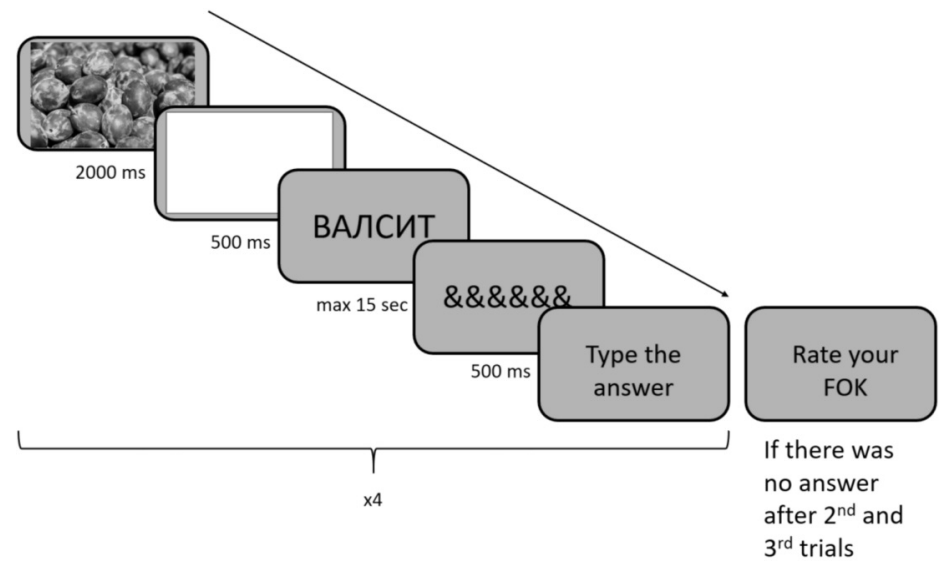


Experimental hypotheses:

H1. There will be more specific intrusion errors (the non-solution word inside the anagram is used as the answer) after interfering priming;

$\mathrm{H} 2$. The FOK ratings will be higher after interfering priming.

It can be argued that we cannot talk about insight problem solving because there is no measurement of the Aha!-experience or another insight's characteristics in the design used in this experiment. However, anagrams are the traditional experimental material in research on insight problem solving. E.M. Lapteva and colleagues (2016) argue that anagrams are mostly solved suddenly even though people obviously make some deliberate efforts such as letter replacements.

\section{Results}

\section{Approbation of the False Semantic Hint Method}

The number of correct answers and different errors is presented in Tables 1 and 2. Specific intrusion errors are those wrong answers that were the same as the false hints. Nonspecific intrusion errors are the wrong answers that are not associated with presented pictures.

A one-way repeated measures ANOVA was conducted to analyse the effect of the priming type on the probability of the correct answer. The number of correct answers (Table 1) in the first attempt is significantly higher $(\mathrm{F}(2,84)=6.65, p<.05)$ and the number of omission errors (Table 2$)$ is significantly lower $(\mathrm{F}(2,84)=$ $6.174, p<.05)$ after the neutral priming. However, the total number of correct answers becomes equal to the fourth attempt. Perhaps, any semantic priming reduces the probability of fast correct answers.

Table 1

Number of the Correct Answers by Priming Type

\begin{tabular}{|c|c|c|c|c|c|c|}
\hline \multirow{2}{*}{ Priming type } & \multicolumn{4}{|c|}{ Attempt } & \multirow{2}{*}{$\begin{array}{c}\text { Total } \\
\text { solved }\end{array}$} & \multirow{2}{*}{ Total } \\
\hline & 1 & 2 & 3 & 4 & & \\
\hline Interfering & 45 & 34 & 22 & 12 & 113 & 268 \\
\hline Irrelevant & 51 & 35 & 14 & 18 & 109 & 269 \\
\hline Neutral & $71^{*}$ & 28 & 16 & 7 & 122 & 269 \\
\hline
\end{tabular}

Table 2

Error Types by Priming Type in the First Attempt

\begin{tabular}{|l|c|c|c|}
\hline \multirow{2}{*}{ Priming type } & \multicolumn{3}{|c|}{ Error type } \\
\cline { 2 - 4 } & Omission & Specific intrusion & Nonspecific intrusion \\
\hline Interfering & 188 & $25^{* * *}$ & 10 \\
\hline Irrelevant & 206 & 1 & 11 \\
\hline Neutral & $176^{* *}$ & 2 & 20 \\
\hline
\end{tabular}

${ }^{*} p<0.05,{ }^{* *} p<0.01,{ }^{* * *} p<0.001$. 
We tested the hypothesis that interfering semantic priming leads to specific intrusion errors. Another one-way repeated measures ANOVA was conducted for this purpose. As it was expected, the probability of specific intrusion errors (Table 2) after interfering priming is significantly higher $(\mathrm{F}(2,84)=15.703, \mathrm{p}<.001)$ than after other types of priming.

\section{Feeling of Knowing Ratings}

There were two measurements of the feeling of knowing in the experiment: FOK1 (30 sec from the start) and FOK2 (45 sec from the start). The mean FOK ratings for each type of priming are presented in Table 3.

We expected higher FOK ratings for anagrams presented after interfering primes. To test this assumption, we performed two mixed-effect linear models (one for each measurement of FOK) with FOK ratings as a dependent variable, the priming type as an independent variable, and participants and stimuli as random effects.

The models were not significant (FOK1: $2(2)=1.808, p>.05$; FOK2: $2(2)=$ $0.503, p>.05)$ and the scores did not differ between conditions neither in the first measurement, nor in the second. It could be argued that the false insights have to be defined not by interfering priming but by the presence of any wrong answer. Following this line, we combined specific and non-specific intrusion errors to one factor (wrong answer) and added it to our model. The mean scores are presented in Table 4. Fifteen participants did not use wrong answers in the first attempt of anagram solving, i.e. they had only correct answers or omission errors. These participants were eliminated from the analysis.

The results of the models are presented in Table 5 (FOK1) and Table 6 (FOK2). For both measurements of FOK, the models with the "Wrong answer" factor significantly differ from those without it $\left(\mathrm{FOK} 1: \chi^{2}(2)=15.384, p<.001\right.$;

Table 3

FOK Ratings by Priming Type

\begin{tabular}{|l|c|c|c|c|}
\hline \multirow{2}{*}{ Priming type } & \multicolumn{2}{|c|}{ FOK1 } & \multicolumn{2}{c|}{ FOK2 } \\
\cline { 2 - 5 } & Mean rate & Std. Dev. & Mean rate & Std. Dev. \\
\hline Interfering & 2.73 & 1.39 & 2.02 & 1.17 \\
\hline Irrelevant & 2.57 & 1.28 & 1.98 & 1.27 \\
\hline Neutral & 2.77 & 1.39 & 2.11 & 1.24 \\
\hline
\end{tabular}

Table 4

FOK Ratings by the Presence of the Wrong Answer in the First Attempt

\begin{tabular}{|l|c|c|c|c|}
\hline \multirow{2}{*}{ Wrong answer } & \multicolumn{2}{|c|}{ FOK1 } & \multicolumn{2}{c|}{ FOK2 } \\
\cline { 2 - 5 } & Mean rate & Std. Dev. & Mean rate & Std. Dev. \\
\hline Yes & 3.05 & 1.49 & 2.41 & 1.69 \\
\hline No & 2.67 & 1.27 & 2.13 & 1.21 \\
\hline
\end{tabular}


Table 5

Mixed-Effect Model for the FOK1 Rating

\begin{tabular}{|l|c|c|c|c|c|c|c|c|}
\hline \multirow{2}{*}{} & \multicolumn{5}{|c|}{ Fixed effects } & \multicolumn{3}{c|}{ Random effects } \\
\cline { 2 - 10 } & $\beta$ & SE & $t$ & CI 2.5\% & CI 97.5\% & Group & Var. & Std. Dev. \\
\hline Intercept & $2.75^{* * *}$ & .20 & 13.66 & 2.34 & 3.15 & Participant & .79 & .89 \\
\hline Irrelevant & -.14 & .13 & -1.07 & -.39 & .11 & Stimulus & .08 & .28 \\
\hline Neutral & -.08 & .13 & -0.62 & -.33 & .17 & Residual & .90 & .95 \\
\hline Wrong answer & $.39^{*}$ & .16 & 2.47 & .08 & .71 & & & \\
\hline
\end{tabular}

Table 6

Mixed-Effect Model for the FOK2 Rating

\begin{tabular}{|l|c|c|c|c|c|c|c|c|}
\hline \multirow{2}{*}{} & \multicolumn{5}{|c|}{ Fixed effects } & \multicolumn{3}{c|}{ Random effects } \\
\cline { 2 - 9 } & $\beta$ & SE & $t$ & CI 2.5\% & CI 97.5\% & Group & Var. & Std. Dev. \\
\hline Intercept & $2.22^{* * *}$ & .20 & 11.02 & 1.81 & 2.62 & Participant & .89 & .94 \\
\hline Irrelevant & -.15 & .12 & -1.25 & -.40 & .09 & Stimulus & 0 & 0 \\
\hline Neutral & -.06 & .12 & -0.47 & -.30 & .19 & Residual & .80 & .90 \\
\hline Wrong answer & $.32 *$ & .15 & 2.06 & .01 & .62 & & & \\
\hline
\end{tabular}

$* p<0.05,{ }^{* * *} p<0.001$.

FOK2: $\left.\chi^{2}(2)=4.225, p<.05\right)$ that allows us to consider the presence of the wrong answer as the key factor.

The results of the models show that the mean FOK ratings are significantly higher for those anagrams that were solved incorrectly relative to those that were not solved at all. In other words, if the individual gives a wrong answer within the first 15 seconds, gets feedback and then thinks another 15 seconds, he or she will rate this anagram higher than those for which there was no answer in the first attempt. And the effect remains to the fourth attempt.

The limitation of the study is that these results are fair for those participants who gave fast wrong answers, and it was only 28 individuals. We suggest that the other 15 participants used a control strategy and checked their hunches before giving answers.

\section{Discussion}

The results of the experiment allow us to draw several conclusions. First of all, we can induce fast wrong solutions (which can be seen as false insights) using semantic priming. This result validates our method, but it has to be noted that the intrusion errors occurred not only after interfering priming but in other conditions as well. Probably, the reason for false insights is not only semantic priming but also the short word per se. One can say that presenting an anagram activates all lexical 
units that can be constructed from the letters. The semantic priming can enforce the activation of a particular unit, and it will be considered as an answer.

Secondly, we proposed that unconscious processes are involved in problem solving, and higher FOK ratings would be the markers of them. Even though there was no direct influence of the priming types on the feeling of knowing, the FOK ratings were surprisingly higher after wrong answers than after omissions. If the processing was totally conscious, there would be no sources of higher FOK ratings. Therefore, we cannot say anything about the particular cognitive mechanisms involved in anagram solving but we can conclude that there is unconscious processing in such a task.

This result also corroborates the hypothesis that metacognitive experiences form in two stages. The first one is the non-specific signal that reflects some properties of the unconscious work (e.g. processing fluency, activation spreading or the coherence between cognitive loops). The second stage is the attribution of this general signal to a particular external or internal source. In our experiment, the unconscious processing activated by priming, and the following anagram leads to the wrong answer and somehow generates the feeling of knowing. We suggest that the initial signal has a sort of aftereffect. It is attributed to the anagram that leads to the fast wrong solution. However, after getting feedback, it has to be attributed to something else. And since participants are asked to rate their feeling of knowing, the initial signal is reattributed to it.

As it was said above, several theories are placing emphasis on the attribution as a stage of metacognition formation. All of them suggest different cognitive processes that generate an initial signal which is then attributed to some source. Despite the fact that this study does not allow us to define what exactly is hidden under "unconscious work", it has to be noted that simple activation theories do not take into account the attribution stage. Also, N. Novemsky with colleagues (Novemsky, Dhar, Schwarz, \& Simonson, 2007) stated based on their experiments that the processing fluency could not be reattributed if it had been assigned to some source. However, our finding demonstrates the possibility of a repeated attribution of the signal, if an individual continues solving the problem. Further investigations are demanded to clarify conditions in which this phenomenon appears.

\section{References}

Allakhverdov, V. M., \& Gershkovich, V. A. (2010). Does consciousness exist? - In what sense? Integrative Psychological and Behavioral Science, 44(4), 340-347. doi:10.1007/s12124-010-9133-8

Allakhverdov, V. M., Gershkovich, V. A., Karpinskaya, V. Y., Moroshkina, N. V., Naumenko, O. V., Tukhtieva, N. H., \& Philippova, M. G. (2015). Heuristic potential of Ya. A. Ponomarev's conception. Psikhologicheskii Zhurnal, 36(6), 24-34. (in Russian)

Bowden, E. M. (1997). The effect of reportable and unreportable hints on anagram solution and the aha! experience. Consciousness and Cognition, 6(4), 545-573. doi:10.1006/ccog.1997.0325

Danek, A. H., \& Wiley, J. (2017). What about false insights? Deconstructing the Aha! experience along its multiple dimensions for correct and incorrect solutions separately. Frontiers in Psychology, 7 , 2077. doi:10.3389/fpsyg.2016.02077 
Dorfman, J., Shames, V. A., \& Kihlstrom, J. F. (1996). Intuition, incubation, and insight: Implicit cognition in problem solving. In G. Underwood (Ed.), Implicit cognition (pp. 257-296). Oxford, UK: Oxford University Press.

Duncker, K. A. (1926). A qualitative (experimental and theoretical) study of productive thinking (solving of comprehensible problems). Journal of Genetic Psychology, 33, 642-708. doi:10.1080/08856559.1926.10533052

Lapteva, E. M., Bondarenko, Ya. A., \& Ushakov, D. V. (2016). Teorii soznaniya i reshenie anagramm [Theories of consciousness and anagrams solving]. Peterburgskiy Psikhologicheskiy Zhurnal, 17, 48-68. (in Russian)

Laukkonen, R., Schooler, J., \& Tangen, J. M. (2018). The Eureka Heuristic: Relying on insight to appraise the quality of ideas. PsyArXiv Preprints. doi:10.31234/osf.io/ez3tn

Metcalfe, J. (1986). Feeling of knowing in memory and problem solving. Journal of Experimental Psychology: Learning, Memory, and Cognition, 12(2), 288-294. doi:10.1037/0278-7393.12.2.288

Newell, A., \& Simon, H. A. (1972). Human problem solving. Englewood Cliffs, NJ: Prentice Hall.

Novemsky, N., Dhar, R., Schwarz, N., \& Simonson, I. (2007). Preference fluency in choice. Journal of Marketing Research, 44(3), 347-356. doi:10.1509/jmkr.44.3.347

Ohlsson, S. (1992). Information-processing explanations of insight and related phenomena. In M. T. Keane \& K. J. Gilhooly (Eds.), Advances in the psychology of thinking (pp. 1-44). London: Harvester-Wheatsheaf.

Peirce, J. W. (2009). Generating stimuli for neuroscience using PsychoPy. Frontiers in Neuroinformatics, 2(10), 1-8. doi:10.3389/neuro.11.010.2008

Poincaré H. (1910). Mathematical creation. The Monist, 20, 321-333. doi:10.1093/monist/20.3.321

Reber, R., Schwarz, N., \& Winkielman, P. (2004). Processing fluency and aesthetic pleasure: Is beauty in the perceiver's processing experience? Personality and Social Psychology Review, 8(4), 364-382. doi:10.1207/s15327957pspr0804_3

Tikhonov, R. V., Ammalainen, A. V., \& Moroshkina, N. V. (2018). The variety of metacognitive feelings: Different phenomena or different terms? Vestnik of Saint Petersburg University. Psychology and Education, 8(3), 214-242. doi:10.21638/11701/ (in Russian)

Topolinski, S., \& Reber, R. (2010). Gaining insight into the "Aha" experience. Current Directions in Psychological Science, 19(6), 402-405. doi:10.1177/0963721410388803

Valueva, E. A., \& Ushakov, D. V. (2015). Signal'naya model' insaita: ot istoricheskikh predposylok k empiricheskim predskazaniyam [The signaling model of insight: from historical preconditions to empirical predictions]. In A. D. Zhuravleva, D. V. Ushakov, \& M. A. Kholodnaya (Eds.), Sovremennye issledovaniya intellekta i tvorchestva [Contemporary research on intellect and creativity] (pp. 15-48). Moscow: Institute of Psychology of the RAS.

Artur V. Ammalainen - Ph.D. student, Department of General Psychology; research assistant, Laboratory of cognitive studies, Saint Petersburg State University.

Research area: cognitive psychology, problem solving, metacognitive experiences, implicit processes in problem solving, Aha!-experience.

E-mail: ammartturi@gmail.com

Nadezhda V. Moroshkina - senior research fellow, Laboratory of Cognitive Studies, Saint Petersburg State University, Ph.D.

Research area: cognitive psychology, implicit learning, problem solving, metacognition, consciousness and cognitive unconsciousness.

E-mail: moroshkina.n@gmail.com 


\title{
Когда ошибка ведет к уверенности: ложный инсайт и чувство знания при решении анаграмм
}

\author{
А.В. Аммалайнен ${ }^{a}$, Н.В. Морошкина ${ }^{a}$ \\ ${ }^{a}$ Санкт-Петербургский государственный университет, 199034, Россия, Санкт-Петербург, \\ Университетская наб., д. 7/9
}

\section{Резюме}

В психологии мышления инсайтом называют внезапное решение задачи, которое сопровождается Ага!-переживанием и высокой уверенностью в ответе. При этом такое решение может оказаться ошибочным, что называется ложным инсайтом. С позиций классических теорий это явление не получает объяснения поскольку в них Ага!-переживание и другие метакогнитивные чувства считаются побочным продуктом когнитивных процессов. Соответственно, такая диссоциация между когнитивными и метакогнитивными процессами невозможна. В сигнальных теориях инсайта предполагается, что формирование метакогнитивных чувств, включая Ага!-переживание, происходит в два этапа. Обнаружение решения на неосознанном уровне порождает неспецифический эмоциональный сигнал, который затем атрибутируется какому-либо процессу или задаче. С этой точки зрения, ложный инсайт и другие несоответствия когнитивных и метакогнитивных процессов возникают по причине неверной атрибуции сигнала. Данная работа была направлена на проверку этой гипотезы. Мы предполагали, что неосознанное решение интерферирующей задачи приведет к ложному инсайту или к повышению чувства знания относительно основной задачи. Для моделирования этой ситуации в экспериментальных условиях была сконструирована методика ложной семантической подсказки. В качестве задач использовались анаграммы, содержащие, помимо решения, слово на одну букву короче верного ответа. Ложной подсказкой выступал интерферирующий семантический прайм - изображение, означающее короткое слово внутри анаграммы. Было обнаружено, что испытуемые делают болыше быстрых ошибок замены после такого прайма. Это подтверждает валидность нашей методики и говорит о том, что при наличии интерферирующей задачи сигнал, возникший при ее решении, может быть неверно атрибутирован основной задаче. Также было зафиксировано повышение оценок чувства знания после ошибок замены по сравнению с ошибками пропуска. Этот результат может быть интерпретирован как последействие первичного метакогнитивного сигнала и возможность его повторной атрибуции.

Ключевые слова: решение задач, семантический прайминг, Ага!-переживание, инсайт, чувство знания, анаграммы, метакогнитивные переживания.

Аммалайнен Артур Вадимович - аспирант, факультет психологии; инженер-исследователь, лаборатория когнитивных исследований, Санкт-Петербургский государственный университет. Сфера научных интересов: когнитивная психология, решение задач, метакогнитивные переживания, имплицитные процессы в решении задач, Ага!-переживание.

Контакты: ammartturi@gmail.com

Морошкина Надежда Владимировна - старший научный сотрудник, лаборатория когнитивных исследований, Санкт-Петербургский государственный университет, кандидат психологических наук.

Сфера научных интересов: когнитивная психология, имплицитное научение, решение задач, метакогниции, сознание и когнитивное бессознательное.

Контакты: moroshkina.n@gmail.com 